\title{
PENGARUH PENGEMASAN VAKUM DAN SUHU PENYIMPANAN TERHADAP DAYA AWET IKAN TONGKOL ASAP
}

\author{
Fredrik Rieuwpassa") dan Endang Sri Heruwati ${ }^{* n}$
}

\begin{abstract}
ABSTRAK
Telah dilakukan penelitian pengasapan ikan tongkol (Eutbynnus affinis) untuk melihat pengaruh pengemasan (vakum dan non-vakum) dan suhu penyimpanan (suhu kamar dan suhu rendah) terhadap daya awet ikan tongkol asap.

Pengujian daya awet ikan tongkol asap dilakukan secara organoleptik dengan mengamati penampakan, bau, rasa, dan tekstur setiap 4 hari selama jarigka waktu 20 hari. Pengamatan kimiawi dilakukan untuk mendukung pengujian daya awet dengan indikator kadar air, jumlah basa menguap (TVB), dan asam tiobarbiturat (TBA). Adapun pengamatan mikrobiologi dilakukan dengan uji jumlah koloni bakteri (TPC) dan jenis kapang maupun bakteri.

Hasil penelitian menunjukkan bahwa kombinasi perlakuan kemasan vakum dan penyimpanan suhu rendah $\left(4^{\circ} \mathrm{C}\right)$ memberikan nilai karakteristik kimia, mikrobiologi dan organoleptik yang lebih baik selama penyimpanan bila dibandingkan dengan perlakuan lain, dan belum ditolak panelis pada hari terakhir pengamatan (hari ke 20). Sebaliknya, ikan tongkol asap yang dikemas non-vakum dan disimpan pada suhu kamar $\left(27-28^{\circ} \mathrm{C}\right)$ telah ditolak panelis pada hari ke 8, sedangkan yang dikemas vakum tetapi disimpan pada suhu kamar dapat bertahan hingga 20 hari penyimpanan.
\end{abstract}

Meskipun dari hasil identifikasi jenis kapang dan bakteri pada percobaan ini tidak ditemukan jenis bakteri dan kapang yang berbahaya, namun dengan kondisi vakum, kemungkinan tumbuhnya bakteri patogen, khususnya yang anaerob, perlu diwaspadai.

\section{ABSTRACT: Effect of Vacuum Packaging and Storage Temperature on the Sheflife of Smoked Skipjack, by: Fredrik Riewropassa and Endang Sri Herwwati}

Research on smoking of skipjack (Eutbynnus affinis) had been conducted to investigate the effect of vacuum packaging and chill storage $\left(4^{\circ} \mathrm{C}\right)$ on the shelflife of smoked product.

The shelflife of the smoked skipjack were determined organoleptically by assessing their appearance, odor, flavor, and texture. The assessment was done every 4 days along the 20-day storage.

Chemical analysis was conducted to support the organoleptic assessment, using moisture content, total volatile bases (TVB), and thiobarbituric acid (TBA) content as indicators of quality changes. Microbiological analysis was also done by counting the total bacteria as well as determining the genus of mold and bacteria which grew on the smoked fish during storage.

Result of the experiment revealed that among the treatments, combined treatment of vacuum package and chill storage seemed to give the longest shelflife as indicated by results of organoleptical, chemical, and microbiological analysis. It was also shown that this method of packaging and storage could maintain the product quality for more than 20 days. On the other hand, when non-vacuum packed product were kept at room temperature $\left(27-28^{\circ} \mathrm{C}\right)$, the fish were rejected by panelists after 8 day storage. Even when they were vacuum packed, room temperature storage could only prolong their shelflife up to 20 days.

Determination of the genus of mold and bacteria which grew on the vacuum packed smoked fish under experimental conditions resulted that no indication of the growth of pathogenic

*) Pengajar di Universitas Pattimura, Ambon
${ }^{* *} \quad$ Peneliti pada Balai Penelitian Perikanan Laut, Jakarta 
organisms. However, alert on the possibility of the occurrence of anaerobic pathogens should be kept in mind.

KEYWORDS: Smoked fish, shelflife, vacuum package

\section{PENDAHULUAN}

Pengasapan adalah cara pengolahan yang selain mengawetkan, juga memberikan rasa dan aroma yang khas. Karena citarasanya yang khas, produk olahan ini hanya berkembang di daerah-daerah yang biasa mengkonsumsi produk tersebut seperti di Maluku, Minahasa, Aceh, Sumatera Selatan, dan Sidoarjo.

Usaha pengolahan ikan asap oleh masyarakat nelayan dan pengusaha saat ini baru mencapai tingkat industri kecil yang pada umumnya dilakukan di daerah perikanan atau perkampungan nelayan. Keadaan sarana pengolahan dan cara penanganan hasil masih belum memenuhi persyaratan yang wajar. Umumnya masa simpan ikan asap pada penyimpanan suhu kamar hanya sekitar satu minggu saja. Dalam usaha memperpanjang masa simpan produk olahan tradisional termasuk ikan asap, beberapa faktor yang perlu diperhatikan antara lain adalah kesegaran ikan, peralatan untuk mengolah, metoda pengolahan, cara pengemasan hasil olahan dan suhu selama penyimpanan.

Pengamatan yang dilakukan oleh Chasanah, Malawat, dan Harwanti (1993) menunjukan bahwa dari beberapa sampel cakalang asap yang diambil di pasar-pasar di Maluku, hampir semua mengandung bakteri faecal coli, Stapbylococcus aureus, dan jamur, dengan jumlah bakteri total antara $10^{4}-10^{5}$ / gram. Keadaan ini menggambarkan rendahnya tingkat sanitasi dan higiene dalam pengolahan ikan asap di daerah tersebut.

Beberapa penelitian telah dilakukan dalam upaya perbaikan pengolahan ikan asap, antara lain dengan perekayasaan alat pengasap yang lebih efektif dan dapat mereduksi waktu pengasapan serta bahan bakar di samping dapat memperbaiki mutu produk akhir (Setiabudi, Syarief, dan Suryanto, 1982; Syarief et al., 1983). Penelitian lain yaitu dengan perendaman ikan dalam larutan garam $10 \%$ selama 1 jam sebelum diasap, yang dimaksudkan untuk mengurangi kadar air dan mengawetkan produk akhir, ternyata tidak memberikan hasil yang memuaskan (Syarief et al., 1983, Bustaman dan Chumaidi, 1981) karena tidak memperpanjang daya awet dan juga tidak berpengaruh terhadap nyata terhadap pembentukan T'VB, amino nitrogen bebas (FAN), pH, dan jumlah bakteri yang ada. Upaya perpanjangan daya awet ikan asap dengan menggunakan bahan pengawet seperti asam sorbat atau garam kaliumnya, dengan atau tanpa dikombinasikan dengan gliserol juga telah dilakukan (Hidayat et al., 1984, Hidayat, Purnomo, dan Rumahrupute, 1993), namun hasil yang diperoleh belum optimal. Penelitian pengemasan dengan kantong plastik berperforasi (Syarief et al., 1983) yang dimaksudkan sebagai upaya 
perlindungan produk setelah diolah pun tidak mampu memecahkan masalah rendahnya daya awet produk.

Berdasarkan pengalaman dari penelitian-penelitian yang telah dilakukan, tampaknya upaya peningkatan mutu dan perpanjangan daya awet ikan asap masih perlu dilakukan.

Penelitian ini bertujuan untuk (1) mempelajari pengaruh pengemasan vakum dan suhu penyimpanan terhadap daya awet ikan tongkol asap, dan (2) mengidentifikasi jenis-jenis kapang dan bakteri yang tumbuh pada produk ikan asap selama penyimpanan. Hasil penelitian ini diharapkan dapat digunakan sebagai informasi bagi nelayan pengolah untuk memperbaiki metoda pengolahan yang telah dilakukan, atau bagi konsumen untuk mengetahui tingkat keamanan produk yang diolah.

\section{BAHAN DAN METODA}

Ikan yang digunakan dalam penelitian ini adalah ikan tongkol (Eutbynnus affinis) sebanyak 150 ekor yang masih segar dengan berat rata-rata 400 gram/ ekor. Ikan tersebut diperoleh dari hasil tangkapan nelayan di Pelabuhanratu, Jawa Barat. Untuk bahan pengawet dipakai garam dapur $(\mathrm{NaCl})$, sedangkan bahan bakar adalah sabut kelapa. Sebagai bahan pengemas digunakan kantong plastik polietilen densitas tinggi (HDPE). Pengemasan vakum dilakukan hingga mencapai tingkat vakum 95\%. Pengasapan dilakukan menggunakan almari pengasap milik Instalasi Penelitian Perikanan Laut Slipi, Jakarta.

Pengolahan ikan tongkol asap dan analisis laboratorium dilakukan di Instalasi Penelitian Perikanan Laut Slipi, Jakarta, sedangkan identifikasi kapang dilakukan di Lab. Mikrobiologi Biotrop Bogor, dan identifikasi bakteri di Lab. PAU-IPB, Bogor.

Ikan tongkol dipilih yang masih segar, kemudian dicuci dengan air bersih untuk menghilangkan kotoran dan lendir yang melekat. Bagian perut dibelah dan isi perut serta insang dikeluarkan. Selanjutnya ikan dicuci untuk membersihkan semua kotoran, darah, dan lendir. Ikan yang telah bersih tersebut kemudian direndam dalam larutan $\mathrm{NaCl} 15 \%$ selama satu jam.

Setelah selesai perendaman, ikan tersebut diangkat dan ditiriskan sekitar 25 menit. Sambil menunggu proses penirisan, almari asap disiapkan dengan menyalakan sabut kelapa. Setelah persiapan dan penirisan selesai, ikan dimasukkan ke dalam almari pengasap dengan menggantungkannya pada batang-batang besi yang dipasang melintang di dalam almari pengasap, lalu pengasapan dimulai.

Suhu pengasapan untuk satu jam pertama adalah $40^{\circ}-50^{\circ} \mathrm{C}$, sedangkan untuk 6 jam berikutnya adalah antara $60^{\circ}-80^{\circ} \mathrm{C}$, diteruskan dengan suhu $40^{\circ}-50^{\circ} \mathrm{C}$ pada satu jam terakhir. Setelah selesai proses pengasapan, ikan dibiarkan pada suhu kamar hingga dingin, kemudian dikemas dengan kantong 
plastik HDPE untuk selanjutnya divakumkan (A1) dan dibiarkan terbuka (A2) serta disimpan pada suhu kamar $\left(27-28^{\circ} \mathrm{C}\right.$ : B1) dan suhu rendah $\left(4^{\circ} \mathrm{C}: \mathrm{B} 2\right)$.

Analisis kimia yang dilakukan meliputi kadar air (dengan metoda oven), jumlah basa menguap (TVB) dengan metode Conway, dan kadar asam tiobarbiturat (TBA) dengan metode Lemon (1975). Uji mikrobiologi dilakukan dengan menghitung jumlah koloni bakteri (TPC) menggunakan media nutrien agar. Nilai organoleptik (penampakan, bau, rasa dan tekstur) ditentukan menggunakan lembar skor (score sheet) berskala 1-9 dengan batas penolakan pada nilai 5. Untuk melihat jenis mikroorganisme yang tumbuh pada ikan asap selama penyimpanan, dilakukan identifikasi kapang dan bakteri. Kecuali itu juga dilakukan analisis kimia untuk melihat kadar protein kasar, lemak, air, garam, fenol, dan formaldehida dari bahan mentah dan produk akhir.

Pengamatan kemunduran mutu dilakukan setiap empat hari, yaitu pada hari ke-0, 4, 8, 12, 16, dan 20. Percobaan ini dirancang dengan rancangan acak lengkap pola faktorial dengan tiga kali ulangan. Analisis data dilakukan dengan uji sidik ragam (anova).

\section{HASIL DAN PEMBAHASAN}

\section{Spesifikasi Bahan Mentah dan Produk Akhir}

Hasil analisis kimia menunjukkan bahwa bahan mentah dan produk akhir ikan tongkol asap mempunyai spesifikasi seperti pada Tabel 1 berikut.

Tabel 1. Spesifikasi bahan mentah dan ikan tongkol asap

Table 1. Specification of raw material and smoked skipjack

\begin{tabular}{|c|c|c|c|}
\hline $\begin{array}{l}\text { Komposisi } \\
\text { Composition }\end{array}$ & & $\begin{array}{l}\text { Bahan mentah } \\
\text { Raw material }\end{array}$ & $\begin{array}{l}\text { Ikan asap } \\
\text { Smoked Skipjack }\end{array}$ \\
\hline - protein & $\%$ & 24,81 & 31,91 \\
\hline - lemak (fat) & $\%$ & 2,34 & 3,02 \\
\hline - air (moisture) & $\%$ & 71,91 & 61,49 \\
\hline - garam (salt) & $\%$ & - & 2,04 \\
\hline - fenol (phenol) & $\mathbf{m g} \%$ & - & 5,79 \\
\hline - Formaldehida (formaldebyde) & $\mathbf{m g} \%$ & - & 15,38 \\
\hline
\end{tabular}

\section{Karakteristik Organoleptik}

Gambar 1, yang menunjukkan nilai rata-rata dari skor penampakan, bau, rasa, dan tekstur, memperlihatkan bahwa perlakuan kemasan non-vakum yang disimpan pada suhu kamar (A1B1) menunjukkan penurunan mutu dengan laju yang paling cepat. Cepatnya laju penurunan mutu ini menyebabkan pengamatan A1B1 terpaksa diakhiri pada hari ke 12. Penurunan mutu terutama 
tampak pada penampakan produk, yang menjadi kusam dan pucat, yang kemungkinan sebagai akibat dari teroksidasinya asam lemak tak jenuh yang terjadi selama penyimpanan (Lawrie, 1974).

Pada perlakuan lain, yakni kemasan vakum yang disimpan pada suhu kamar (A2B1) tidak berbeda nyata dengan kemasan non-vakum yang disimpan pada suhu rendah (A1B2). Perlakuan kemasan vakum yang disimpan pada suhu rendah (A2B2) tampaknya merupakan perlakuan yang terbaik, karena memberikan laju penurunan mutu yang terendah. Perlakuan A1B1 melewati batas penerimaan (nilai 5) pada hari ke 8, sedangkan A2B1 dan A1B2 pada hari ke 20. Perlakuan A2B2, sampai pada hari terakhir pengamatan (hari ke 20) masih mencapai nilai di atas 5,5. Di sini terlihat bahwa efek sinergestik antara suhu dan kondisi vakum sangat nyata.

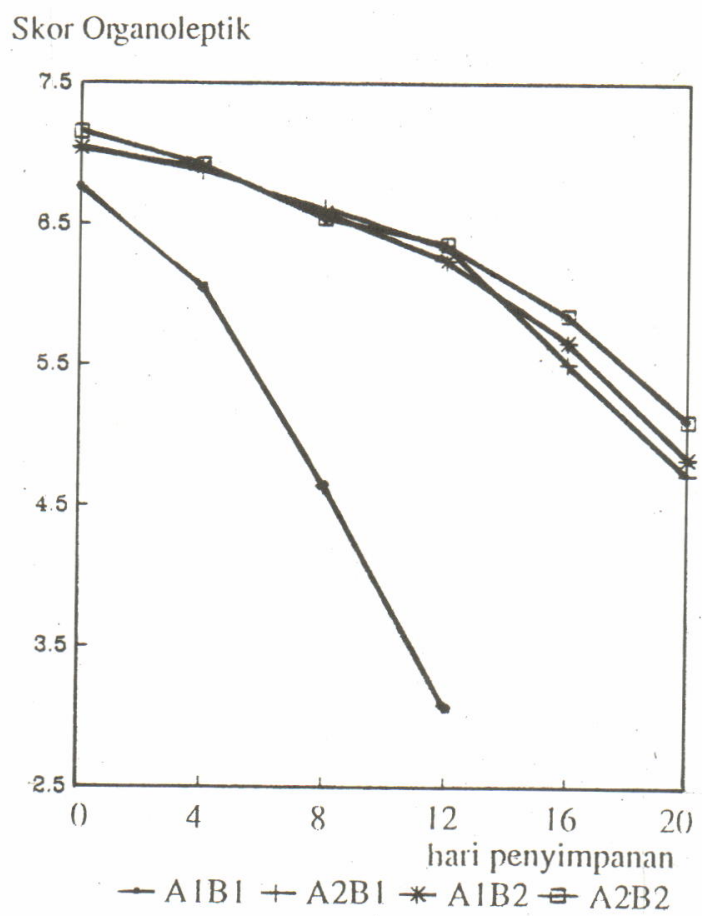

Gambar 1. Perubahan mutu organoleptik ikan tongkol asap selama penyimpanan

Figure 1. Changes of organoleptic quality of smoked skipjack during storage

Keterangan (Logend):

A1B1: derigan kemasan non-vakum, disimpan pada suhu kamar (non-vacuum packed, room temperature storage) A1B2: dengan kemasan non-vakum, disimpan pada suhu rendah (non-vacuum packed, chill storage)

A2B1: dengan kemasan vakum, disimpan pada suhu kamar (vacuum packed, room temperature storage)

A2B2: dengan kemasan vakum, disimpan pada suhu rendah (vacuum packed, chill storage) 


\section{Kadar Air}

Selama penyimpanan, baik pada suhu kamar maupun pada suhu rendah, produk yang dikemas non-vakum ternyata menurun kadar airnya dengan laju yang lebih cepat dibandingkan dengan produk yang dikemas vakum. Plastik relatif bersifat kedap udara sehingga dapat mempertahankan kandungan air (Winarno, Fardiaz dan Fardiaz, 1980). Perlakuan pengemasan vakum menghambat terjadinya transfer dari produk ke udara sekitarnya dan berakibat tidak berkurangnya kadar air ikan asap yang dikemas vakum (Gambar 2).

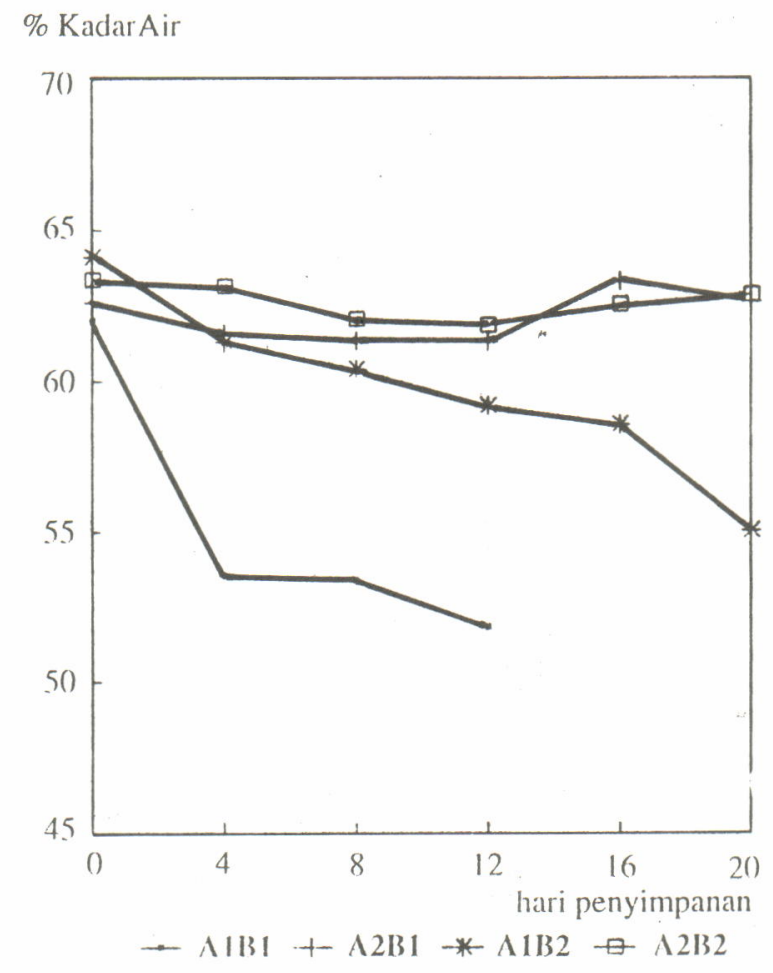

Gambar 2. Perubahan kadar air ikan tongkol asap selama penyimpanan Figure 2. Changes of moisture content of smoked skipjack during storage

\section{Keterangan (Legend):}

A1B1: dengan kemasan non-vakum, disimpan pada suhu kamar (non-vacuum packed, room temperature storage) A1B2: dengan kemasan non-vakum, disimpan pada suhu rendah (non-vacuum packed, chill storage) A2B1: dengan kemasan vakum, disimpan pada suhu kamar (vacuum packed, room temperature storage) A2B2: dengan kemasan vakum, disimpan pada suhu rendah (vacuum packed, chill storage) 


\section{Kandungan 'TVB}

Peningkatan kandungan TVB disebabkan karena basa-basa menguap yang dihasilkan dari penguraian protein seperti amoniak dan amina (James, 1978). Dalam penelitian ini, kandungan TVB ikan tongkol asap mengalami peningkatan selama penyimpanan (Gambar 3). Dilihat dari kenaikan kandungan TVB selama periode penyimpanan, ternyata mutu ikan tongkol asap dengan perlakuan kemasan vakum yang disimpan pada suhu rendah (A2B2) adalah yang paling baik bila dibandingkan dengan perlakuan lain, diikuti oleh perlakuan kemasan non-vakum pada suhu rendah (A1B2). Adapun perlakuan kemasan vakum dan non-vakum yang disimpan pada suhu kamar (A2B1 dan A1B1) mempunyai laju peningkatan TVB yang nyata lebih cepat. $\mathrm{Hal}$ ini menunjukkan bahwa perlakuan suhu lebih efektif dalam menghambat pembentukan TVB daripada perlakuan kemasan.

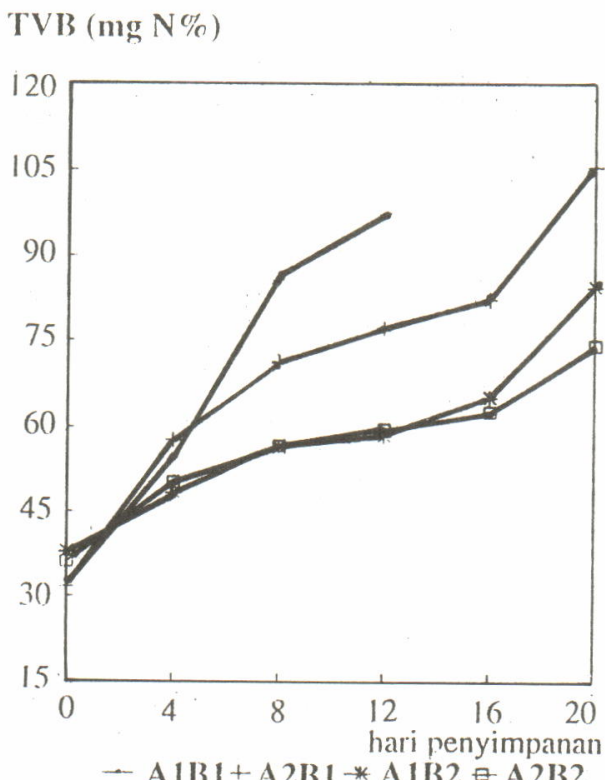

Gambar 3. Perubahan kadar TVB ikan tongkol asap selama penyimpanan Figure 3. Changes of TVB content of smoked skipjack during storage

A1B1: dengan kemasan non-vakum, disimpan pada suhu kamar (non-vacuum packed, room temperature storage) A1B2: dengan kemasan non-vakum, disimpan pada suhu rendah (non-vacuum packed, chill storage) A2B1: dengan kemasan vakum, disimpan pada suhu kamar (vacuum packed, room temperature storage) A2B2: dengan kemasan vakum, disimpan pada suhu rendah (vacuum packed, chill storage) 
Dikaitkan dengan perubahan organoleptik yang terjadi, tampaknya hanya perlakuan yang ekstrim (kemasan non-vakum suhu kamar saja yang nyata berkorelasi dengan nilai TVB. Pengaruh suhu yang nyata terlihat pada pembentukan TVB (pada perlakuan A1B2, A2B1,atau A2B2) tidak tampak dari perubahan organoleptik.

\section{Kandungan TBA}

Kandungan TBA ikan tongkol asap untuk semua perlakuan mengalami peningkatan (Gambar 4). Pada gambar tersebut terlihat bahwa kemasan vakum rata-rata memperlihatkan nilai TBA yang lebih rendah dibandingkan kemasan non-vakum. Pengemasan vakum dapat menekan proses oksidasi seoptimal mungkin (Tatum et al., 1977), karena selama penyimpanan, oksidasi tetap berlangsung sesuai permeabilitas kemasan terhadap oksigen. Kemasan vakum berperan dalam memperlambat laju oksidasi lipida yang berpengaruh terhadap pembentukan malonaldehida (Bird and Draper, 1982).

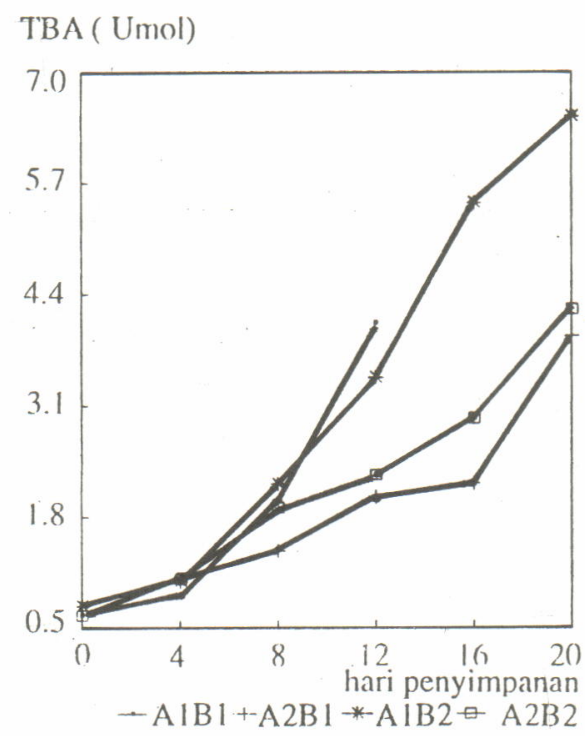

Gambar 4. Perubahan kadar TBA ikan tongkol asap selama penyimpanan Figure 4. Changes of TBA content of smoked skipjack during storage 
Hal yang menarik untuk dicatat di sini adalah adanya perbedaan efek suhu dan kemasan untuk setiap parameter yang berlainan. Dengan menggunakan parameter TBA ternyata hanya kemasan yang berpengaruh sedangkan suhu penyimpanan tidak. Ini berlawanan dengan bila menggunakan parameter TVB. Penjelasan dari fenomena ini adalah bahwa pembentukan TBA sangat berkaitan dengan terjadinya proses oksidasi, sehingga faktor pengemasan menjadi sangat berpengaruh. Sebaliknya, pembentukan TVB sangat berkaitan dengan proses pembusukan ikan yang merupakan akibat dari aktivitas bakteri, sehingga faktor suhu menjadi lebih dominan. Walaupun demikian, bila dikaitkan dengan perubahan mutu organoleptik, terdapat kesamaan antara parameter TBA dengan TVB.

\section{Kandungan 'TPC}

Perubahan jumlah bakteri ikan asap selama penyimpanan (Gambar 5) menunjukkan bahwa semua perlakuan mengalami peningkatan dengan pola yang sama dengan pola perubahan TVB, yaitu pengaruh suhu yang lebih nyata dibandingkan dengan pengaruh kemasan. Ini menunjukkan bahwa bakteri berperan dalam pembentukan TVB. Setelah 12 hari penyimpanan pada suhu kamar, produk yang dikemas non-vakum (A1B1) telah mengandung bakteri sejumlah $10^{6}-10^{7}$ /gram ikan asap. Jumlah bakteri yang sama baru dicapai oleh produk yang dikemas vakum yang disimpan pada suhu kamar (A2B1) pada hari ke 20. Sedangkan produk yang disimpan pada suhu rendah, baik yang dikemas vakum maupun non-vakum (A2B2 dan A1B2), kandungan bakteri pada hari ke 20 hanya mencapai $10^{4}-10^{5} /$ gram ikan asap. Dilihat dari kenaikan kandungan TPC ternyata ikan tongkol asap dengan perlakuan kemasan vakum dan penyimpanan suhu rendah (A2B2) adalah yang paling baik. Pengemasan vakum sebenarnya menguntungkan karena selain mencegah kontaminasi bahan-bahan dari luar dan mencegah pertumbuhan bakteri aerob, juga dapat mempertahankan mutu produk melalui pencegahan oksidasi, kehilangan air serta mempertahankan warna selama transportasi (Jeremiah et al., 1972). Namun demikian pemilihan parameter jumlah bakteri total untuk melihat pengaruh pengemasan vakum mungkin kurang tepat berhubung masih dapat tumbuhnya bakteri anaerob pada kondisi vakum.

\section{Identifikasi Kapang dan Bakteri}

Berdasarkan hasil identifikasi kapang pada ikan tongkol asap dari semua perlakuan selama penyimpanan, ditemukan 3 jenis kapang yang tumbuh pada produk tersebut yaitu Aspergillus niger, Aspergillus flavus,dan Penicillium digitatum. Sedangkan dari identifikasi bakteri ditemukan 10 jenis yaitu Stapbylococcus sp., Micrococcus sp., Bacillus sp., Corynebacter sp., Acinetobacter sp., Flavobacterium sp., Enterobacter sp., Alcaligenes sp., Kurthia sp. dan Pseudomonas sp.. Secara lebih rinci, jenis kapang dan bakteri yang ditemukan pada setiap perlakuan suhu dan kemasan dapat dilihat pada Tabel 2. 
Log jumlah Bakteri

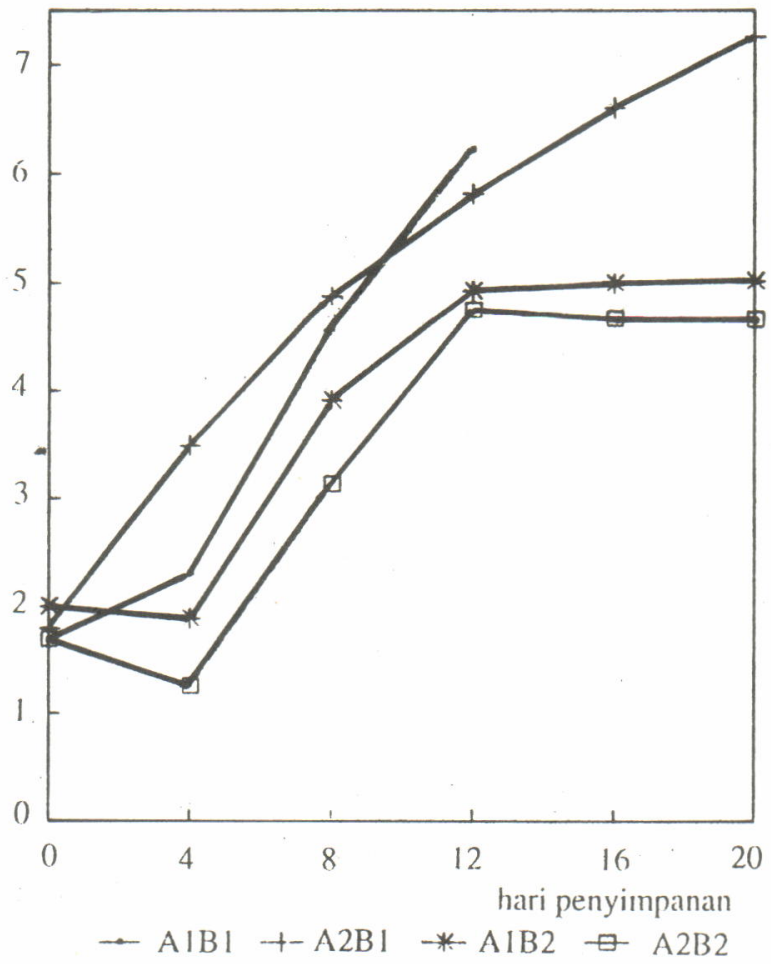

Gambar 5. Perubahan jumlah bakteri ikan tongkol asap selama penyimpanan Figure 5. Changes of total bacteria of smoked skipjack during storage

\section{Keterangan (Logend:}

A1B1: dengan kemasan non-vakum, disimpan pada suhu kamar (non-vacuum packed, room temperature storage) A1B2: dengan kemasan non-vakum, disimpan pada suhu rendah (non-vacuum packed, chill storage) A2B1: dengan kemasan vakum, disimpan pada suhu kamar (vacuum packed, room temperature storage) A2B2: dengan kemasan vakum, disimpan pada suhu rendah (vacuum packed, chill storage)

Secara khusus, pengamatan Clostridium botulinum memang tidak dilakukan dalam penelitian ini, namun demikian ternyata dari hasil identifikasi bakteri tidak dijumpai clostridium. Akan tetapi mengingat kondisi vakum sangat potensial bagi pertumbuhan bakteri patogen tersebut, maka bahaya oleh bakteri clostridium tetap perlu diwaspadai. Apalagi dengan tumbuhnya kapang A.flavus yang dikenal menghasilkan aflatoksin yang bersifat karsinogenik pada perlakuan kemasan vakum yang disimpan pada suhu kamar, aplikasi teknologi pengemasan vakum pada ikan asap ini perlu dipertimbangkan masak-masak. 
Tabel 2. Jenis kapang dan bakteri pada setiap perlakuan

Table 2. Mold and Bacteria grew under treated conditions

\begin{tabular}{|c|c|c|}
\hline $\begin{array}{l}\text { Perlakuan } \\
\text { Treatment }\end{array}$ & $\begin{array}{l}\text { Jenis } \\
\text { Genus }\end{array}$ & $\begin{array}{l}\text { Lama simpan (hari) } \\
\text { Storage time (days) }\end{array}$ \\
\hline
\end{tabular}

Kapang (mold)

1. Non-vakum, suhu kamar $\quad$ P.digitatum 7

(Non-vacuum, room temp.) A.niger

2. Vakum, suhu kamar A.niger

(Vacuum, room temp.)

A.flavus

3. Non-vakum, suhu rendah tidak terdeteksi (Non-vacuum, chill temp.) undetected

4. Vakum, suhu rendah tidak terdeteksi

(Vacuum, chill temp.)

undetected

\section{Bakteri (bacteria)}

1. Non-vakum, suhu kamar Enterobacter

(Non-vacuum, room temp.) Micrococcus

Staphylococcus

Flavobacterium

Bacillus

Corynebacterium

2. Vakum, suhu kamar Corynebacterium

(Vacuum, room temp.)

Staphylococcus .

Flavobacterium

3. Non-vakum, suhu rendah Corynebacterium

(Vacuum, chill temp.)

Staphylococcus

4. Vakum, suhu rendah Staphylococcus (Vacuum, chill temp.)

\section{KESIMPULAN DAN SARAN}

Ikan tongkol asap dengan perlakuan kemasan non-vakum yang disimpan pada suhu kamar telah melewati batas penerimaan panelis pada hari ke 8. Ini didukung dengan data analisis kesegaran secara kimiawi. Perlakuan kemasan vakum yang disimpan pada suhu ruang serta perlakuan kemasan non-vakum yang disimpan pada suhu rendah ditolak panelis pada hari ke 20. Penurunan mutu secara kimiawi terjadi sejajar dengan pola penurunan mutu organoleptik. Adapun kemasan vakum yang disimpan pada suhu rendah, secara organoleptis maupun kimiawi masih belum mengalami kerusakan mutu yang berarti. 
Perlakuan pengemasan tampaknya berpengaruh nyata terhadap penurunan kadar air dan pembentukan TBA, sedangkan perlakuan suhu berpengaruh pada perkembangan jumlah bakteri yang selanjutnya juga berpengaruh terhadap pembentukan TVB pada produk ikan asap.

Hasil identifikasi kapang dan bakteri pada produk ikan tongkol menunjukkan bahwa ditemukan kapang $A$.flavus, yang potensial sebagai penyebab kanker pada perlakuan kemasan vakum yang disimpan pada suhu kamar. Walaupun bakteri penyebab penyakit atau keracunan dan yang berbahaya bagi kesehatan konsumen tidak ditemukan dalam penelitian ini, aplikasi teknologi kemasan vakum, apalagi tanpa penyimpanan pada suhu rendah, perlu diwaspadai.

Disarankan agar penelitian ini diikuti dengan kajian dari segi ekonomi, sehingga dapat dipilih cara pengolahan mana yang layak, tidak saja dari segi teknis, tetapi juga ekonomis.

\section{DAFTAR PUSTAKA}

Bird R.P. and H.H.Draper, 1982. Uptake and Oxidation of Malonaldehyde by Cultured Mammalian Cells. Lipid 17:8.

Bustaman S. dan A.Choliq C., 1981. Studi pendahuluan kemunduran mutu bakalang asar. Bull. Penel. Perik.Vol.1 Nó.2:209-280

Chasanah E., S.Malawat, dan S.Harwanti, 1993. Kondisi mikrobiologi pengolahan dan pemasaran cakalang asar di P. Ambon. Jurn. Penel. Perik. Laut No.83:90-95

Hidayat, Nur, A.H.Purnomo, dan B.Rumahrupute, 1993. Pengaruh penambahan bahan pengawet dan perubahan cara pengolahan terhadap daya awet cakalang asar. Jurn. Penel. Tekn. Perik. No.73:25-34

Hidayat, Nur, L.Hutuely, N.Hasan, T.A.R.Hanafiah, 1984. Pengaruh penambahan potasium sorbat pada pengolahan cakalang asar terhadap daya awetnya. Lap. Penel. Tekn. Perik. No.33:33-43

James J.M., 1978. Modern Food Microbiology. Second edition. Van Nostrand Reinhold Company,N.Y.

Jeremiah L.E., G.C.Smith and Z.L.Carpenter, 1972. Vacuum Packaging of Lamb and Effect of Storage Temperature. J. Food Sci. Vol.37:457-462.

Lawrie R.A., 1974. Meat Science. Second edition. Pergamon Press.Oxford, N.Y.,Toronto

Lemon D.W., 1975. An Improved TBA test for Rancidity. New Fisheries Circular No.51. Halifax Laboratory, Fisheries and Marine Service. Environment Canada, Halifax Nova Scotia. 
Setiabudi E., F.Syarief, dan D.Suryanto, 1982. Introduksi prototipe alat pengasar ikan. Lap. Penel. Tekn. Perik. No.16:17-24

Syarief F., S.Bustaman, D.Suryanto, dan B.Rumahrupute, 1983. Peningkatan teknik pengolahan cakalang asar di Ambon. Lap. Penel. Tekn. Perik. No.21:21-28.

Tatum J.D., G.C.Smith and Z.L.Carpenter, 1972. Packaging System for Transport and Storage of Lamb. J. Food Sci. 42:6.

Winarno F.G., S.Fardiaz dan D.Fardiaz, 1980. Pengantar Tehnologi Pangan. P.T. Gramedia, Jakarta. 
